\title{
Determinants of Non-Performing Loans: Evidence from Europe
}

\author{
Antonio Salvi ${ }^{1}$, Candida Bussoli ${ }^{1}$, Lavinia Conca ${ }^{1} \&$ Marisa Gigante $^{1}$ \\ ${ }^{1}$ Department of Economics and Management, University LUM Jean Monnet, Italy \\ Correspondence: Antonio Salvi, Department of Economics and Management, University LUM Jean Monnet, \\ Casamassima (BA), Italy. E-mail: salvi@lum.it
}

Received: March 29, 2018

doi:10.5539/ijbm.v13n10p230
Accepted: August 21, 2018

Online Published: September 25, 2018

\begin{abstract}
The issue of banks' loan quality has assumed growing importance at the international level. This study aims to tackle the issue and to verify the impact of bank-specific determinants and macroeconomic indicators on banks' loan quality.

The analysis is conducted on a sample of 2,816 European banks over the period 2011-2015 through a multivariate regression with panel data.

The main evidence shows that a higher return on average assets and a greater soundness of the bank can be associated with a better loan quality. Furthermore, the results also demonstrate that system conditions can contribute to determining banks' asset quality. Adverse cyclical conditions, resulting from a lower GDP growth and a higher unemployment rate, can generate a lower loan quality.
\end{abstract}

Keywords: bank, doubtful loans, non-performing loans

\section{Introduction}

The issue of banks' loan quality has been broadly debated at the international level and has aroused great interest among experts in the financial industry, particularly with the worsening of the financial crisis.

Studies have given particular attention to the relationships between bank-specific determinants and macroeconomic determinants and banks' credit quality. In particular, the literature is oriented along two lines of analysis: one line focuses on the incidence of macroeconomic determinants only on the loan quality (Babouček and Jančar, 2005; Marcucci and Quagliarello, 2008; Nkusu, 2011), while the other additionally considers the impact of the macroeconomic components on banks' credit (Salas and Saurina, 2002; Jiménez and Saurina, 2006; Boudriga et al., 2009; Makri et al., 2014).

The connection between macroeconomic conditions and banks' credit has been underlined by empirical evidence. Empirical studies demonstrate that favourable macroeconomic conditions, such as sustained economic growth, low unemployment and low interest rates, tend to be associated with a better banks' loan quality. Similarly, bank-specific variables related to financial features and management policies are of great importance.

This work belongs to the second line of research, as it aims to demonstrate the impact of bank-specific determinants and macroeconomic indicators on the impaired loans to gross loans ratio and on the doubtful loans to total assets ratio in the period following the outbreak of the sovereign debt crisis.

Therefore, this study provides new empirical evidence on the phenomenon by focusing the attention on a difficult period characterized by a high incidence of non-performing loans in the European credit system.

The empirical analysis is carried out on a sample of 2,816 banks, divided into 443 commercial banks, 1,403 cooperative banks and 970 savings banks based in Europe over the period 2011-2015 through a multivariate regression with panel data.

The main results show a negative relationship between loan quality and the return on average assets and the total capital ratio, the latter being a proxy of the capital adequacy ratio. A higher return on average assets and a higher soundness of the banks can be associated with a better loan quality.

The empirical evidence also demonstrates a negative relationship between the doubtful loans to total assets ratio and the bank size. Therefore, the results suggest that large banks have a greater ability to assess and manage doubtful loans than smaller banks have. 
With regard to macroeconomic indicators, the analysis shows that loan quality has a positive relationship with the unemployment rate and a negative relationship with GDP, highlighting that adverse economic conditions can lead to a deterioration of banks' loan quality.

The paper is structured as follows. Section 2 illustrates the literature leading to the research hypothesis, and section 3 shows the empirical analysis in terms of the survey methodology used (section 3.1), the examined sample (section 3.2), and the results from the study (section 3.3). The last section outlines the conclusive considerations and implications of the studied phenomenon.

\section{Literature Review}

\subsection{Macroeconomic Determinants of Banks' Credit Quality}

Macroeconomic determinants that impact banks' credit quality are the subject of empirical studies that support the positive relationship between economic growth conditions and better loan quality. Numerous authors examine this relationship, and there is a substantial consensus on the association between higher economic growth, lower unemployment and incidence of impaired loans.

Babouček and Jančar (2005) analysed the links between loan quality and macroeconomic shocks in the Czech banking sector over the period 1993-2006. Empirical evidence shows a significant and positive relationship between non-performing loans, unemployment rate and consumer price inflation. Therefore, economic growth influences the banking sector's stability.

Quagliariello (2007) examined the performance of banks and the riskiness of bank credit in Italy using a large sample of banks observed over the period between 1985 and 2002. The contribution notes that non-performing loans and loan loss provisions are generally low in growth periods, and they increase in periods of downturn.

Furthermore, Marcucci and Quagliarello (2008) investigated the effects of the economic cycle on the default rate of loans at the national level over the period 1990-2004. The results show that default rates follow a cyclical pattern; in particular, they decrease during periods of economic expansion and increase in periods of downturn.

Some studies have examined the feedback effects from the banking system to the real economy in a cross-country perspective; among these Nkusu (2011) investigated the relationships between non-performing loans (NPLs) and macroeconomic performance over the period between 1998 and 2009. Empirical analysis highlights that in advanced economies, adverse macroeconomic developments affect loan quality and that in turn, higher NPLs lead to a decline in GDP growth.

\subsection{Microeconomic and Macroeconomic Determinants of Credit Quality}

An important line of literature has considered, jointly, the impact of economic and financial indicators of bank-related and macroeconomic determinants on banks' credit.

At the international level, several studies have been carried out to analyse banks' credit quality, among them: Makri et al. (2014) for the Eurozone countries; Klein (2013) for the Central, Eastern and South-Eastern European countries; Škarica (2014) for the Central and Eastern Europe countries; Messai and Jouini (2013) for Italy, Greece and Spain; other studies have shown the experiences of banking systems in individual countries, such as Salas and Saurina (2002) and Jiménez and Saurina (2006) for Spain or Pittaluga and Morelli (1998), D'Amico and Biscotti (2013), and Chiorazzo et al. (2014) for Italy.

Some studies have noted that the NPLs affect micro and macroeconomic factors. For example, Messai and Jouini (2013) examined a sample of 85 banks in Italy, Greece and Spain in the period 2004-2008 and identified the micro and macroeconomic determinants of NPLs through panel data analysis. Their study highlights the negative relationship between the NPL ratio, the growth rate of GDP, and the profitability of bank assets and positive relationship between non-performing loans and unemployment rate.

The contribution of Makri et al. (2014) investigated the determinants that affect the non-performing loans in the banking systems of 14 Eurozone countries exclusively in the pre-crisis period using a dynamic panel regression analysis. The authors' results reveal strong links between the NPL ratio and macroeconomic variables (public debt, unemployment, and growth rate of GDP) and the bank's specific determinants (the capital adequacy ratio and profitability expressed by the return on equity).

Finally, De Bock and Demyanets (2012) assessed the vulnerability of emerging markets and their banks to financial shocks during the period 1996-2010, analysing the determinants of banks' credit quality through OLS, country-specific fixed effects and the Generalized Method of Moments (GMM). The main determinants affecting non-performing loans in the countries subject to analysis are loan growth, GDP growth and exchange rate. Furthermore, the evidence shows that economic activity tends to slow down with the rise in NPLs and with the 
depreciation of exchange rates.

Several studies attribute a greater impact on credit quality to the economic-financial component than to the macroeconomic component, among them Salas and Saurina's work (2002), which examines a sample of Spanish banks in the period 1985 to 1997 through multivariate regressions. The study focuses on the impact that economic-financial and macroeconomic indicators have on the NPLs and total loans ratio by comparing commercial banks and savings banks. Concerning the effect produced by macroeconomic variables, similar results are observed for both categories of banks, while concerning the specific bank variables, the results are partially different. Economic and financial indicators have higher explanatory power for savings banks than for commercial banks. The analysis shows a significant positive relationship among bank problem loans and growth policies, net interest margin, managerial inefficiency, and loan portfolio composition for savings banks and a negative relationship with bank size and capital ratio for commercial banks.

In a recent study, Boudriga et al. (2009) identified the cross-country determinants of NPLs for a sample of 59 countries observed over the period 2002-2006, using several econometric techniques. From this analysis, it emerges that the non-performing loans are mainly influenced by bank-specific determinants; in particular, the paper highlights that a higher capital adequacy ratio and prudent provisioning policy seem to reduce the level of problem loans.

The contribution of Chiorazzo et al. (2014) analysed the impact of both the economic and financial components and the macroeconomic determinants of the credit risk of 38 Italian banking groups in the period 2006-2012. The work is conducted through both the cross-sectional analysis of bank-specific determinants of risk and dynamic panel regressions. The authors demonstrate that the increased credit risk tends to occur in less efficient and less profitable banks. The study notes a significant relationship between bank size and risk, noting that larger credit institutions present a slightly higher level of risk than smaller ones. Finally, the work relates the evidence of bank-specific characteristics to macroeconomic indicators, confirming the relevance of the impact of the bank's financial and economic indicators on credit risk.

In contrast with previous studies, some authors have underlined that macroeconomic determinants have a greater impact compared to the specific characteristics of individual banks.

Klein (2013) examined the level of NPLs in the ten largest banks in Central, Eastern and South-Eastern Europe, with particular reference to commercial banks, cooperative banks, savings banks, and real estate and mortgage between 1998 and 2011. The analysis highlights how the level of NPLs can be determined both by specific banks' indicators and by macroeconomic conditions, although the latter has higher explanatory power. The macroeconomic variables that have a higher impact on non-performing loans are the GDP growth, inflation and unemployment. In particular, the level of NPLs tends to increase with rising unemployment and inflation rates. Furthermore, the study shows that non-performing loans are also sensitive to bank-specific factors, as the analysis indicates that higher profitability contributes to lower NPLs. These bank-level effects are significant in pre and post-crisis periods.

Škarica (2014) analysed and quantified the impact of financial and macroeconomic variables on asset quality in Central and Eastern European countries over the period 2007-2012 through a fixed effects model. The results suggest that the main cause of high levels of NPLs is represented by the economic slowdown, which is statistically significant, and that the low real GDP growth has been the main factor of the increase of the NPLs.

With particular reference to the Italian banking system, Pittaluga and Morelli's work (1998) examined the causes of the increase in bad loans registered in Italy during the nineties. They try to demonstrate whether the increase of credit risk can be attributed to the behaviour of the banks, in terms of customer selection criteria, or to factors related to the worsening of the real economy. The evidence of the study supports the hypothesis that the increase in bad loans in Italy is due to a downturn in the economy.

More recent studies on bad loans have been conducted by Bofondi and Ropele (2011), who observe the impact of main macroeconomic components such as GDP, unemployment and inflation rates, and other indicators on the banks' loan quality with regard to the households and firms in the years 1990-2010. The authors conclude that at the national level, the credit risk evolution is consistent with fluctuations in macroeconomic variables.

Lastly, several contributions have paid particular attention to the issue of cooperative credit, which has assumed a significant role both at the European and at the national level in recent years, since it has proved to be particularly solid in spite of the dramatic recession. This is mainly due to its traditional structure, historically characterized by the strong prevalence of credit intermediation activities in favour of households and firms, a strong local root and a balance sheet structure that is broadly balanced (Banca d' Italia, 2009). Cooperative banks are smaller than other 
intermediaries operating in the banking system, representing significant differences within the same category.

An analysis conducted by Di Salvo (2011) highlighted similarities and differences between the systems of cooperative banks in Germany, France, Finland, Spain, the Netherlands, Austria, Portugal and Italy considering the peculiarities of individual countries and the institutional context within which each banking system is located. The analysis emphasizes the organizational-strategic framework of the cooperative banks and on the evolving trends that will characterize cooperative banks over the coming years.

Cooperative banks have faced a number of transformations including the new complexity of macroeconomic phenomena, the dynamics of financial markets and its consequences in terms of systemic risks and the most stringent prudential rules of patrimonial and organizational nature (Boscia and Lopez, 2011).

Some studies have focused on cooperative banks credit management by examining the characteristics of intermediaries, such as the size and type of customers, and demonstrated how their specificities affect the riskiness of the loan portfolio (Ferri and Di Salvo, 1994).

In particular, D'Amico and Biscotti (2013) investigated the influence of the bank-specific components such as profitability, total loans, loan growth rate, bank size and number of bank branches on bad loans of the cooperative banks of a specific Italian geographic area in the period between 1995 and 2009. The results show positive and significant relations between the bad loans and the bank size, loans and number of branches. The study is developed in a further analysis that links the bad loans with bank-specific variables, governance and macroeconomic indicators. The evidence shows a positive relationship among bad loans the number of bank branches and bank size and a negative relationship between the level of bad loans and ROAA.

In a recent study, Bussoli et al. (2016) examined a sample composed of 60 Italian banks between 2008 and 2014, focusing on the impact of the economic and financial indicators of credit institutions and the macroeconomic indicators on credit quality in terms of both the impaired loans to gross loans ratio and the doubtful loans in bank balances. The results highlight that, with reference to the financial and economic components of the bank, both the impaired loans to gross loans ratio and the doubtful loans to total assets ratio are negatively related to the profitability and bank size and that, as regards macroeconomic determinants, the unemployment rate has a negative influence on credit quality.

In the light of the analysed literature, it is possible to assert that the banks' asset quality can be determined by the specific characteristics of credit intermediaries as well as by macroeconomic variables.

The research hypotheses are as follows.

H1: There is a significant relationship between the bank loan quality and the conditions of profitability and soundness of European banks.

H2: There is a significant relationship between the bank loan quality and the size of European banks.

H3: There is a significant relationship between the bank loan quality and the system conditions in which European banks operate.

H4: There is a significant relationship between the incidence of doubtful loans and the conditions of profitability and soundness of European banks.

H5: There is a significant relationship between the incidence of doubtful loans and the size of European banks.

H6: There is a significant relationship between the incidence of doubtful loans and the system conditions in which European banks operate.

\section{Empirical Analysis}

\subsection{Methodology}

To verify the research hypotheses, an analysis has been carried out by a multivariate regression with panel data over the period 2011-2015. The models are illustrated below:

$$
\begin{aligned}
& \text { Imp_gl } \mathrm{it}_{\mathrm{it}}=\beta_{0}+\beta_{1} \mathrm{ROAA}_{\mathrm{it}-1}+\beta_{2} \mathrm{CI}_{\mathrm{it}-1}+\beta_{3} \mathrm{IM}_{\mathrm{it}-1}+\beta_{4} \mathrm{Lsize}_{\mathrm{it}-1}+\beta_{5} \mathrm{Tcr}_{\mathrm{it}-1}+\beta_{6} \mathrm{Inf}_{\mathrm{it}-1}+\beta_{7} \mathrm{Une}_{\mathrm{t}-1}+\beta_{8} \mathrm{LGDP}_{\mathrm{t}-1}+\eta_{i t}+\varepsilon_{\mathrm{t}}(1) \\
& \text { Dbtf_ta } a_{i t}=\beta_{0}+\beta_{1} \text { ROAA }_{\mathrm{it}-1}+\beta_{2} \mathrm{CI}_{\mathrm{it}-1}+\beta_{3} \mathrm{IM}_{\mathrm{it}-1}+\beta_{4} \mathrm{Lsize}_{\mathrm{it}-1}+\beta_{5} \operatorname{Tcr}_{\mathrm{it}-1}+\beta_{6} \operatorname{Inf}_{\mathrm{it}-1}+\beta_{7} \operatorname{Une}_{\mathrm{t}-1}+\beta_{8} \mathrm{LGDP}_{\mathrm{t}-1}+\eta_{i t}+\varepsilon_{\mathrm{t}}(2) \\
& \text { The dependent variables are as follows: }
\end{aligned}
$$

- Imp_gl: indicates the bank's loan quality; the variable is constructed as the ratio of impaired loans to gross loans of the bank; the data are collected from the Orbis database;

- Dbtf_ta: indicates the incidence of doubtful loans on total assets; the variable is constructed as the ratio of 
doubtful loans to total assets; the data are collected from the Orbis database.

The independent variables examined for the years 2011-2015 include both the economic and financial indicators and the macroeconomic variables. The economic and financial indicators are described in Table 1, while the macroeconomic indicators are described in Table 2.

Table 1. Economic and financial Indicators

\begin{tabular}{lll}
\hline Acronym & & Description \\
\hline ROAA & Return on Average Assets & the efficiency with which the bank uses its assets to generate income \\
CI & Cost income & management efficiency indicator \\
IM & Net Interest Margin & characteristic lucrative margin of bank \\
Lsize & Total assets of bank & size of bank \\
Tcr & Total capital ratio & capital adequacy ratio \\
\hline
\end{tabular}

Table 2. Macroeconomic Indicators

\begin{tabular}{lll}
\hline Acronym & & Description \\
\hline Inf & Inflation & Harmonised Indices of Consumer Prices (HICP) \\
Une & Unemployment & Unemployment rate \\
LGDP & Annual GDP & Gross Domestic Product \\
\hline
\end{tabular}

Since the credit quality is affected by the policies adopted by the bank over time, by its financial characteristics and by the macroeconomic determinants of previous periods, it has been chosen to apply the lag periods widely used in the literature (Salas \& Saurina, 2002; Jiménez \& Saurina, 2005; Boudriga et al., 2009; Nkusu, 2011; De Bock \& Demyanets, 2012; Makri et al., 2014). Applying the lag periods to the independent variables reduces potential endogeneity problems.

The Pooled model is supported by the results of collinearity and heteroskedasticity tests; in particular, the variance inflation factor (VIF) is used to verify multicollinearity, and the White test is used to ensure that the model was not spoiled by heteroskedasticity. To consider the presence of heteroskedasticity problems, we use a robust standard error analysis.

The Hausman test supports the choice between panel analysis with fixed effects or with random effects.

$\eta_{i t}$ denotes all the unobservable characteristics of the firms that vary across firms but are assumed constant for each firm, and $\varepsilon_{i t}$ represents a random disturbance.

In view of making more rigorous analysis and gathering the heterogeneity on the temporal component, it has been considered appropriate to insert time dummy variables.

\subsection{Sample}

The analysis is carried out on a sample composed of 2,816 European banks considered in the period 2011-2015. The data have an annual frequency. The final dataset includes an unbalanced panel of 2,816 active banks in the 28 member states of the European Union (EU28), divided into 443 commercial banks, 1,403 cooperative banks and 970 savings banks. Financial data are obtained from the "Orbis" database and macroeconomic data from the "Eurostat" website.

The main descriptive statistics of the studied variables and the correlation analysis are reported in Tables 3 and 4 . The correlation analysis highlights negative and significant correlations between dependent variables and bank-specific variables, with particular reference to the return on average assets $(R O A A)$ and the total capital ratio $(T c r)$. Table 4 shows that both the impaired loans to gross loans ratio and doubtful loans to total assets ratio have a positive correlation with the unemployment rate (Une). 
Table 3. Descriptive Statistics (2011-2015)

\begin{tabular}{lrrrr}
\hline & Min & Max & Mean & Std. Dev. \\
\hline Imp_gl & -0.037 & 33.427 & 6.719 & 67.530 \\
Dbtf_ta & 0.003 & 0.467 & 0.048 & 0.0406 \\
ROAA & -3.043 & 2.791 & 0.317 & 0.4529 \\
CI & 30.041 & 147.951 & 75.201 & 15.7408 \\
IM & 0.055 & 4.650 & 2.101 & 0.5923 \\
Lsize & 9.710 & 16.609 & 12.829 & 1.3495 \\
Tcr & 8.944 & 68.480 & 18.720 & 6.4296 \\
Inf & -1.600 & 5.800 & 1.583 & 1.0807 \\
Une & 4.600 & 27.500 & 6.873 & 3.5267 \\
GDP & 7.600 & 267.000 & 117.605 & 23.6734 \\
\hline
\end{tabular}

Table 4. Correlation Matrix (2011-2015)

\begin{tabular}{|c|c|c|c|c|c|c|c|c|c|c|}
\hline & $\left|m p \_g\right|$ & Dbtf_ta & ROAA & $\mathrm{Cl}$ & IM & Lsize & $\mathrm{Tcr}$ & $\operatorname{lnf}$ & Une & LGDP \\
\hline Imp_gl & 1 & & & & & & & & & \\
\hline Dbtf_ta & & 1 & & & & & & & & \\
\hline ROAA & $-0.2502 *$ & $-0.4167^{*}$ & 1 & & & & & & & \\
\hline $\mathrm{Cl}$ & $-0.3317 *$ & 0.0320 & $-0.3572 *$ & 1 & & & & & & \\
\hline IM & 0.0187 & 0.0275 & $0.0366 *$ & $-0.0386 *$ & 1 & & & & & \\
\hline Lsize & $-0.0683 *$ & $0.1690 *$ & $-0.1071 *$ & $-0.0755^{*}$ & $-0.1650 *$ & 1 & & & & \\
\hline Tcr & $-0.0416^{*}$ & $-0.2215^{*}$ & $0.1548^{*}$ & $-0.0320 *$ & $0.0452 *$ & $-0.2532 *$ & 1 & & & \\
\hline Inf & $0.6363^{*}$ & $0.2563^{*}$ & $-0.0415^{*}$ & $-0.3446 *$ & -0.0021 & 0.0158 & -0.0177 & 1 & & \\
\hline Une & $0.0597 *$ & $0.1980 *$ & $0.0731^{*}$ & $-0.0534 *$ & $0.0650^{*}$ & $-0.2468 *$ & $-0.0659 *$ & $-0.1020 *$ & 1 & \\
\hline LGDP & $-0.4234 *$ & 0.0045 & $0.0727^{*}$ & $0.1438^{*}$ & $-0.2436^{*}$ & $-0.0504 *$ & 0.0136 & $-0.4355^{*}$ & $0.0798^{*}$ & 1 \\
\hline
\end{tabular}

* Correlation is significant at the 0.05 level (2-tailed).

\section{Results}

The analysis is carried out on both dependent variables in a multivariate regression with panel data over the period 2011-2015. The Pooled OLS model is supported by the results of the collinearity and heteroscedasticity analysis. The collinearity test allows the exclusion of problems of collinearity among the variables, while the problem of heteroscedasticity determines the use of analysis with robust standard errors.

Table 5 illustrates in detail the results related to the dependent variable expressed by the ratio of impaired loans to gross loans (Imp_gl). As a result of Hausman's test, the fixed effects model with time dummy variables is chosen.

With particular reference to economic and financial indicators, the empirical evidence shows a negative and significant relationship between the impaired loans to gross loans ratio (Imp_gl) and the return on average assets $($ ROAA_l). Furthermore, the results note a negative relationship between the dependent variable (Imp_gl) and the total capital ratio $\left(T c r_{-} 1\right)$.

Thus, a greater return on average asset and a greater soundness of the European banks tends to be associated with a better loan quality.

The evidence allows the conclusion that the first research hypothesis is verified for the dependent variable relative to loan quality.

By contrast, it is not possible to observe a significant relationship with the bank size, since bank size does not seem to have an impact on the incidence of impaired loans to gross loans.

Therefore, the second research hypothesis is not verified.

Regarding macroeconomic determinants, the analysis highlights a positive relationship between the unemployment rate (Une_l) and the loan quality (Imp_gl) and a negative relationship between the dependent variable and the gross domestic product, expressed in natural logarithm (LGDP_l).

The presence of a positive relationship with the unemployment rate and a negative relationship with the gross domestic product indicates that adverse system conditions can negatively affect the dependent variable (Imp_gl) and result in a worse quality of bank loans.

In the light of these results, it is possible to argue that the third research hypothesis is verified. 
Table 5. Regression Model - Imp_gl (2011-2015)

\begin{tabular}{|c|c|c|c|c|c|c|c|c|c|c|}
\hline \multirow[t]{2}{*}{ Models } & \multicolumn{2}{|c|}{ Pooled OLS } & \multicolumn{2}{|c|}{ Fixed Effects } & \multicolumn{2}{|c|}{ Random Effects } & \multicolumn{2}{|c|}{ Fixed Effects } & \multicolumn{2}{|c|}{ Random Effects YD } \\
\hline & Coeff. & $p$-value & Coeff. & $p$-value & Coeff. & $p$-value & Coeff. & $p$-value & Coeff. & $p$-value \\
\hline \multirow[t]{2}{*}{ Const. } & $-9.3859 *$ & 0.104 & $24.08029 * *$ & 0.031 & -246688 & 0.358 & $32.42982 * *$ & 0.021 & $17.13631^{* * *}$ & 0.001 \\
\hline & (5.76520) & & (11.1782) & & $(2.68425)$ & & (14.0197) & & $(5.29408)$ & \\
\hline \multirow[t]{2}{*}{ ROAA_1 } & $-5.17936 * * *$ & 0.000 & $-1.18812^{* * *}$ & 0.000 & $-2.06463^{* * *}$ & 0.000 & $-1.26637^{* * *}$ & 0.000 & $-2.03079 * * *$ & 0.000 \\
\hline & $(0.33305)$ & & $(0.25950)$ & & $(0.25390)$ & & $(0.26412)$ & & $(0.25756)$ & \\
\hline \multirow[t]{2}{*}{ Cl_1 } & $-0.05740 * * *$ & 0.000 & $-0.02372 * * *$ & 0.000 & $-0.02796 * * *$ & 0.000 & $-0.02137 * * *$ & 0.000 & $-0.02453^{* * *}$ & 0.000 \\
\hline & $(0.00684)$ & & $(0.00454)$ & & $(0.00465)$ & & $(0.00446)$ & & $(0.00455)$ & \\
\hline \multirow[t]{2}{*}{ IM_1 } & $1.65685^{* * *}$ & 0.000 & 0.61995 & 0.866 & $0.81188^{* * *}$ & 0.001 & 0.12536 & 0.732 & $0.79425^{* * *}$ & 0.001 \\
\hline & (0.21799) & & $(0.36832)$ & & $(0.24985)$ & & $(0.36582)$ & & $(0.23797)$ & \\
\hline \multirow[t]{2}{*}{ Lsize_1 } & $0.12531^{*}$ & 0.072 & -0.55748 & 0.528 & -0.16152 & 0.853 & -0.76788 & 0.390 & -0.55748 & 0.528 \\
\hline & (0.06969) & & $(0.88418)$ & & $(0.08746)$ & & $(0.89344)$ & & $(0.88418)$ & \\
\hline \multirow[t]{2}{*}{ Tcr_1 } & $-0.05024 * * *$ & 0.006 & -0.04634 & 0.143 & $-0.05679 * * *$ & 0.004 & $-0.05788^{*}$ & 0.075 & $-0.05827^{* * *}$ & 0.004 \\
\hline & $(0.01818)$ & & $(0.03165)$ & & (0.01979) & & $(0.03234)$ & & $(0.01997)$ & \\
\hline \multirow[t]{2}{*}{ Inf_1 } & $-0.35966^{* * *}$ & 0.003 & $-0.33716^{* * *}$ & 0.000 & $0.14579 * *$ & 0.055 & -0.60315 & 0.214 & 0.15714 & 0.789 \\
\hline & $(0.11952)$ & & $(0.08802)$ & & $(0.07612)$ & & $(0.48513)$ & & $(0.58796)$ & \\
\hline \multirow[t]{2}{*}{ Une_1 } & $1.63962 * * *$ & 0.000 & $0.92850 * * *$ & 0.000 & $1.51552 * * *$ & 0.000 & $1.15833^{* * *}$ & 0.000 & $1.61151^{* * *}$ & 0.000 \\
\hline & $(0.04192)$ & & $(0.08015)$ & & (0.05117) & & $(0.24703)$ & & $(0.06250)$ & \\
\hline \multirow[t]{2}{*}{ LGDP_1 } & 1.10039 & 0.352 & $-2.80976^{* * *}$ & 0.000 & $-1.00699 * *$ & 0.039 & $-4.33726 * * *$ & 0.000 & $-4.49485^{* * *}$ & 0.000 \\
\hline & (1.18259) & & $(0.42516)$ & & $(0.48807)$ & & (1.02782) & & $(1.13636)$ & \\
\hline Yd_2011 & & & & & & & yes & & yes & \\
\hline Yd_2012 & & & & & & & yes & & yes & \\
\hline Yd_2013 & & & & & & & yes & & yes & \\
\hline Yd_2014 & & & & & & & yes & & yes & \\
\hline \multirow[t]{8}{*}{ Yd_2015 } & & & & & & & yes & & yes & \\
\hline & & & $F(8,1752)$ & 84.06 & & & & & & \\
\hline & $R^{2}$ & 0.65 & P-value(F) & 0.000 & & & & & & \\
\hline & $F(8,1338)$ & 574.44 & Hausman & 371.97 & & & & & & \\
\hline & P-value(F) & 0.000 & P-value $\left({ }^{x^{2}}\right)$ & 0.000 & & & & & & \\
\hline & & & $\begin{array}{l}\text { Number of } \\
\text { obs }\end{array}$ & 3780 & $\begin{array}{l}\text { Number of } \\
\text { obs }\end{array}$ & 3780 & $\begin{array}{l}\text { Number of } \\
\text { obs }\end{array}$ & 3780 & $\begin{array}{l}\text { Number of } \\
\text { obs }\end{array}$ & 3780 \\
\hline & & & $\begin{array}{l}\text { Number of } \\
\text { groups }\end{array}$ & 1753 & $\begin{array}{l}\text { Number of } \\
\text { groups }\end{array}$ & 1753 & $\begin{array}{l}\text { Number of } \\
\text { groups }\end{array}$ & 1753 & $\begin{array}{l}\text { Number of } \\
\text { groups }\end{array}$ & 1753 \\
\hline & & & $\begin{array}{l}\text { Obs for } \\
\text { each group }\end{array}$ & 2.2 & $\begin{array}{l}\text { Obs for each } \\
\text { group }\end{array}$ & 2.2 & $\begin{array}{l}\text { Obs for } \\
\text { each group }\end{array}$ & 2.2 & $\begin{array}{l}\text { Obs for } \\
\text { each group }\end{array}$ & 2.2 \\
\hline
\end{tabular}

With regard to the second dependent variable, measured by the ratio of doubtful loans to total assets (Dbtf_ta), in line with the results of Hausman's test, we have considered the fixed effects model with time dummy variables.

The evidence presented in Table 6 shows a negative and significant relationship between the incidence of doubtful loans to total assets ( $\left.D b t f_{-} t a\right)$, the return on average assets (ROAA_1), and the cost income (CI_1). A greater return on average assets of the bank is associated with a reduction of the incidence of doubtful loans.

A significant and positive relationship between the dependent variable (Dbtf_ta) and the total capital ratio (Tcr_1) can be observed, which implies that greater financial soundness can positively affect and reduce the incidence of doubtful loans to total assets. Furthermore, the empirical analysis detects a negative and statistically significant relationship between the incidence of doubtful loans to total assets (Dbtf_ta) and bank size (Lsize_1), highlighting how larger credit institutions can be associated with a lower incidence of doubtful loans to total assets.

This evidence leads to the verification of the fourth and fifth hypotheses for the dependent variable (Dbtf_ta).

With reference to macroeconomic determinants, no statistically significant relationship is observed between the incidence of doubtful loans and the macroeconomic variables; therefore, the sixth research hypothesis is not verified for the second dependent variable (Dbtf_ta), and it is possible to state that bank-specific characteristics have a greater impact compared to macroeconomic variables on the incidence of doubtful loans in the balance sheet of European banks. 
Table 6. Regression Model - Dbtf_ta (2011-2015)

\begin{tabular}{|c|c|c|c|c|c|c|c|c|c|c|}
\hline \multirow[t]{2}{*}{ Models } & \multicolumn{2}{|c|}{ Pooled OLS } & \multicolumn{2}{|c|}{ Fixed Effects } & \multicolumn{2}{|c|}{ Random Effects } & \multicolumn{2}{|c|}{ Fixed Effects YD } & \multicolumn{2}{|c|}{ Random Effects YD } \\
\hline & Coeff. & $p$-value & Coeff. & $p$-value & Coeff. & $p$-value & Coeff. & $p$-value & Coeff. & $p$-value \\
\hline \multirow[t]{2}{*}{ Const. } & $-0.52661 * *$ & 0.012 & $2.80668 * * *$ & 0.000 & -0.20996 & 0.220 & 0.37770 & 0.827 & $-0.32867^{* *}$ & 0.017 \\
\hline & $(0.21027)$ & & $(0.76400)$ & & (0.17131) & & (1.72713) & & $(0.13732)$ & \\
\hline \multirow[t]{2}{*}{ ROAA_1 } & $-0.03322 * * *$ & 0.000 & $-0.01115^{* * *}$ & 0.000 & $-0.01485^{* * *}$ & 0.000 & $-0.01125^{* * *}$ & 0.000 & $-0.01477^{* * *}$ & 0.000 \\
\hline & $(0.00237)$ & & $(0.00176)$ & & $(0.00183)$ & & $(0.00174)$ & & $(0.00184)$ & \\
\hline \multirow[t]{2}{*}{ Cl_1 } & $-0.00042^{* * *}$ & 0.000 & $-0.00049 * * *$ & 0.000 & $-0.00041^{* * *}$ & 0.000 & $-0.00045^{* * *}$ & 0.000 & $-0.00033^{* * *}$ & 0.000 \\
\hline & $(0.00008)$ & & $(0.00009)$ & & $(0.00007)$ & & (0.00009) & & $(0.00007)$ & \\
\hline \multirow[t]{2}{*}{ IM_1 } & $0.01981^{* * *}$ & 0.000 & 0.00124 & 0.625 & $0.00727^{* * *}$ & 0.000 & 0.00159 & 0.531 & $0.00856^{* * *}$ & 0.000 \\
\hline & $(0.00206)$ & & $(0.00253)$ & & $(0.00205)$ & & $(0.00254)$ & & $(0.00205)$ & \\
\hline \multirow[t]{2}{*}{ Lsize_1 } & $0.00621^{* * *}$ & 0.000 & -0.01491 & 0.103 & $0.00448^{* *}$ & 0.015 & $-0.01510 *$ & 0.095 & $0.00501^{* * *}$ & 0.006 \\
\hline & $(0.00103)$ & & $(0.00912)$ & & $(0.00184)$ & & $(0.00903)$ & & $(0.00182)$ & \\
\hline \multirow[t]{2}{*}{ Tcr_1 } & $-0.00051^{* * *}$ & 0.000 & $-0.00073 * * *$ & 0.004 & $-0.00062 * * *$ & 0.000 & $-0.00078 * * *$ & 0.002 & $-0.00068 * * *$ & 0.000 \\
\hline & $(0.00013)$ & & $(0.00025)$ & & $(0.00016)$ & & $(0.00025)$ & & $(0.00016)$ & \\
\hline \multirow[t]{2}{*}{ Inf_1 } & $-0.00474 * * *$ & 0.000 & $0.00298^{* *}$ & 0.049 & $-0.00304 * * *$ & 0.000 & -0.00484 & 0.477 & -0.00205 & 0.737 \\
\hline & (0.00099) & & $(0.00150)$ & & $(0.00061)$ & & $(0.00680)$ & & $(0.00611)$ & \\
\hline \multirow[t]{2}{*}{ Une_1 } & $0.00384 * * *$ & 0.000 & $-0.00257^{* *}$ & 0.058 & $0.00276 * * *$ & 0.000 & 0.00060 & 0.959 & $0.00625^{* * *}$ & 0.000 \\
\hline & $(0.00078)$ & & $(0.00135)$ & & $(0.00051)$ & & $(0.01175)$ & & $(0.00153)$ & \\
\hline \multirow[t]{2}{*}{ LGDP_1 } & $0.09984 * *$ & 0.026 & $-0.54261 * * *$ & 0.000 & 0.04358 & 0.219 & -0.01979 & 0.955 & $0.05744 *$ & 0.049 \\
\hline & $(0.04481)$ & & $(0.15455)$ & & $(0.03543)$ & & $(0.34696)$ & & $(0.02923)$ & \\
\hline Yd_2011 & & & & & & & yes & & yes & \\
\hline Yd_2012 & & & & & & & yes & & yes & \\
\hline Yd_2013 & & & & & & & yes & & yes & \\
\hline Yd_2014 & & & & & & & yes & & yes & \\
\hline \multirow[t]{8}{*}{ Yd_2015 } & & & & & & & yes & & yes & \\
\hline & $R^{2}$ & 0.395 & $F(8,1752)$ & 41.76 & & & & & & \\
\hline & $F(8,1338)$ & 71.72 & P-value(F) & 0.000 & & & & & & \\
\hline & P-value(F) & 0.000 & Hausman & 1103.96 & & & & & & \\
\hline & & & $P$-value $\left({ }^{2}\right)$ & 0.000 & & & & & & \\
\hline & & & $\begin{array}{l}\text { Number of } \\
\text { obs }\end{array}$ & 1355 & $\begin{array}{l}\text { Number of } \\
\text { obs }\end{array}$ & 1355 & $\begin{array}{l}\text { Number of } \\
\text { obs }\end{array}$ & 1355 & $\begin{array}{l}\text { Number of } \\
\text { obs }\end{array}$ & 1355 \\
\hline & & & $\begin{array}{l}\text { Number of } \\
\text { groups }\end{array}$ & 415 & $\begin{array}{l}\text { Number of } \\
\text { groups }\end{array}$ & 415 & $\begin{array}{l}\text { Number of } \\
\text { group }\end{array}$ & 415 & $\begin{array}{l}\text { Number of } \\
\text { groups }\end{array}$ & 415 \\
\hline & & & $\begin{array}{l}\text { Obs for } \\
\text { each group }\end{array}$ & 3.3 & $\begin{array}{l}\text { Obs for each } \\
\text { group }\end{array}$ & 3.3 & $\begin{array}{l}\text { Obs for } \\
\text { each group }\end{array}$ & 3.3 & $\begin{array}{l}\text { Obs for } \\
\text { each group }\end{array}$ & 3.3 \\
\hline
\end{tabular}

\section{Conclusions}

This study has investigated the existence of significant relationships between loan quality and the incidence of doubtful loans on the balance sheets of European banks and bank profitability, soundness and size. It also investigates the influence of macroeconomic determinants.

With regard to the bank-specific component, the empirical analysis reveals that a higher return on average assets and a higher capital adequacy ratio can be associated with a better loan quality (Salas and Saurina, 2002; Boudriga et al.,2009; D'amico and Biscotti, 2013, Makri et al., 2014). Greater profitability and soundness, as well as a larger bank size, are associated with a lower incidence of doubtful loans to total assets in the balance sheet.

With regards to the macroeconomic determinants, the evidence shows a positive relationship between loan quality and the level of unemployment, indicating that an increase of the latter, that is, a worse condition of the economic system can negatively affect credit quality (Babouček and Jančar, 2005; Bofondi and Ropele, 2011; Nkusu, 2011; Klein, 2013; Messei and Jouini; 2013; Škarica, 2014).

Moreover, the results show a negative relationship with the gross domestic product, which is in line with the reference literature (Nkusu, 2011; De Bock and Demyanets, 2012; Messei and Jouini, 2013; Škarica, 2014), highlighting, even in this case, that a negative economic situation can lead to an increase in the incidence of impaired loans to gross loans.

The results suggest that in the European context and the years following the outbreak of the sovereign debt crisis, larger banks with positive indicators of profitability and soundness showed a better capacity to evaluate the 
creditworthiness of firms and reduce the incidence of doubtful loans. The system conditions, however, have influenced these dynamics in the pejorative sense, increasing the difficulties of the credit institutions.

\section{References}

Babouček, I., \& Jančar, M. (2005). Effect of macroeconomic shocks to the quality of the aggregate loan portfolio. Czech National Bank. Working Paper Series 1, 1-62.

Bofondi, M., \& Ropele, T. (2011). Macroeconomic determinants of bad loans: Evidence from Italian banks. Banca d'Italia. Occasional Papers, 89, 14-17.

Boscia, V., \& Lopez, J. (2011). Il posizionamento del sistema cooperativo del Credito nel sistema bancario italiano. In Carretta A. (Ed.), Il credito cooperativo: Storia, diritto, economia, organizzazione. IL MULINO, Bologna.

Boudriga, A., Taktak, N. B., \& Jellouli, S. (2009). Banking supervision and nonperforming loans: a cross-country analysis. Journal of Financial Economic Policy, 1(4), 286-318. https://doi.org/10.1108/17576380911050043

Bussoli, C., Conca, L., Gigante, M., \& Madaro, G. (2016). Determinants of Impaired Loans and Doubtful Loans in Italy. Journal of Business and Economics, 7(8), 1215-1225. https://doi.org/10.15341/jbe(2155-7950)/08.07.2016/003

Chiorazzo, V., Masala, F., \& Morelli, P. (2014). Le determinanti bank-specific del deterioramento del credito: evidenze da un nuovo e più ampio indicatore di rischio. Bancaria, 5, 23-49.

Cotugno, M. (2016). Credito non-performing e forborne exposure: nuove regole e implicazioni gestionali. Bancaria, 6, 78-86.

D'Amico, E., \& Biscotti, A. M. (2013). Credit risk, the case of Italian cooperative banks. Bancaria, 1, 28-39.

De Bock, R., \& Demyanets, A. (2012). Bank Asset Quality in Emerging Markets: Determinants and Spillovers. IMF Working paper, 12(71), 1-26.

Di Salvo, R. (2011). I sistemi di banche cooperative in Europa. Governance, assetti strategici e tendenze evolutive. In Carretta A. (Ed.), Il credito cooperativo: Storia, diritto, economia, organizzazione. IL MULINO, Bologna.

Ferri, G., \& Di Salvo, R. (1994). Credito cooperativo, finanziamento alle piccole imprese e sviluppo economico decentrato: valutazione teoriche e primi riscontri empirici. Cooperazione di Credito, 55(4), 309-369.

Hoggarth, G., Sorensen, S., \& Zicchino, L. (2005). Stress Tests of UK Banks Using a VAR Approach. Bank of England. Working Paper 282, 1-44.

Jiménez, G., \& Saurina, J. (2006). Credit cycles, credit risk and prudential regulation. International Journal of Central Banking, 2(2), 65-98.

Kalirai, H., \& Scheicher, M. (2002). Macroeconomic Stress Testing: Preliminary Evidence for Austria. Austrian National Bank Financial Stability Report, 3, 58-74.

Klein, N. (2013). Bank Asset Quality in Emerging Markets: Determinants and Spillovers. IMF Working paper, 13(72), 1-26.

Makri, V., Tsagkanos, A., \& Bellas A. (2014). Determinants of Non-Performing Loans: The Case of Eurozone. Panoeconomicus, 61(2), 193-206. https://doi.org/10.2298/PAN1402193M

Marcucci, J., \& Quagliariello, M. (2008). Is Bank Portfolio Risk Procyclical? Evidence from Italy Using a Vector Autoregression. Journal of International Financial Markets, Institutions and Money, 18(1), 46-63.

Messai, A. S., \& Jouini, F. (2013). Micro and Macro Determinants of Non-performing Loans. International Journal of Economics and Financial Issues, 3(4), 852-860.

Nkusu, M. (2011). Nonperforming Loans and Macrofinancial Vulnerabilities in Advanced Economies. IMF Working paper, 11(61), 1-27.

Penza, P., \& Benzi, S. (2013). I crediti deteriorati in Europa: un'analisi comparata di regole e prassi. Bancaria, 9 , $2-16$.

Pittaluga, G. B., \& Morelli, P. (1998). Le sofferenze bancarie: Tendenze e Previsioni. Bancaria Editrice, 40-42.

Quagliariello, M. (2007). Banks' Riskiness Over the Business Cycle: A Panel Analysis on Italian Intermediaries. Applied Financial Economics, 17(2), 119-138. 
Rinaldi, L., \& Sanchis-Arellano, A. (2006). Household debt Sustainability: What explains Household Non-performing Loans? An empirical Analysis. ECB Working paper, 570, 18-21.

Salas, V., \& Saurina, J. (2002). Credit Risk in Two Institutional Regimes: Spanish Commercial and Savings Banks. Journal of Financial Services Research, 22(3), 203-224.

Škarica, B. (2014). Determinants of non-performing loans in Central and Eastern European countries. Financial Theory and Practice, 38(1), 37-59. https://doi.org/10.1023/A:1019781109676

\section{Copyrights}

Copyright for this article is retained by the author(s), with first publication rights granted to the journal.

This is an open-access article distributed under the terms and conditions of the Creative Commons Attribution license (http://creativecommons.org/licenses/by/4.0/). 